\title{
COMPARISON OF SCHEDULE DELAY AND CAUSAL FACTORS BETWEEN TRADITIONAL AND GREEN CONSTRUCTION PROJECTS
}

\author{
Bon Gang HWANG ${ }^{\mathrm{a}}$, Lay Peng LEONG \\ ${ }^{a}$ Department of Building, National University of Singapore, Singapore \\ ${ }^{\mathrm{b}}$ Department of Cost Control, EC Harris Singapore Pte Ltd, Singapore
}

Received 07 September 2011; accepted 23 February 2013

\begin{abstract}
Despite the heighten focus on environmental sustainability for green construction, rare research has been conducted to analyze such projects, especially in the aspect of their schedule delay and causal factors. Conducting a survey in which 30 companies in the Singapore construction industry participated, this study first identified the degree of project delay in 220 traditional and 96 green construction projects performed in Singapore. Next, a set of factors affecting project delay was identified based on various literatures to determine the most influential factors for both green and traditional projects. The analysis result established that $15.91 \%$ of the traditional projects were delayed while $32.29 \%$ of the green construction projects were completed behind schedule. Furthermore, the top 5 factors causing delay in green projects were: (1) speed of decision making by client; (2) speed of decision making involving all project teams; (3) communication/coordination between key parties; (4) level of experience of consultants; and (5) difficulties in financing project by contractors. Lastly, recommendations were introduced to reduce schedule delay in green construction projects based on the analysis results. This study will serve as s a base for further research on the enhancement of green construction schedule performance.
\end{abstract}

Keywords: green construction, delay, schedule performance, project management, Singapore.

Reference to this paper should be made as follows: Hwang, B. G.; Leong, L. P. 2013. Comparison of schedule delay and causal factors between traditional and green construction projects, Technological and Economic Development of Economy 19(2): 310-330.

JEL Classification: L74, O22, O32, O53.

\section{Introduction}

The construction industry is a key economic growth sector in Singapore and plays a dominant role in providing employment to support the future development of Singapore (Navon 2005). According to the Building and Construction Authority (BCA) (Building and Construction

Corresponding author Bon Gang Hwang

B. G. Hwang E-mail: bdghbg@nus.edu.sg 
Authority 2011), the value of construction contracts to be awarded in 2011 and 2012 would be between $\$ 18$ and $\$ 25$ billion, and it will continue to escalate over the next 2-3 years.

With the mounting global concern on the environment, Singapore has also shifted its focus to making sustainable development a key national priority as well (Singapore Green Building Council 2009; Kua 2006; Hwang, Tan 2012). Green building is believed to be a more eco-friendly approach in most aspects. Since the launch of BCA's Green Mark Scheme in 2005, the number of green mark certified buildings have increased to 440 from the mere 17 in 2005 (The Business Times 2010). In addition to the green mark scheme, BCA also formulated the 1st and 2nd Green Building Masterplan together with other efforts to thrust forward in developing more green buildings in Singapore. By year 2030, the Inter-Ministerial Committee on Sustainable Development (IMCSD) targets to have at least $80 \%$ of the building in Singapore to achieve the BCA green mark certified rating (BCA 2009). Furthermore, in order to intensify the efforts in speeding up the development of green buildings in Singapore, all new building developments and major renovations which are over $2000 \mathrm{~m} 2$ in size are required to achieve green mark certifications (Building and Construction Authority 2008). As such, construction of green buildings is gaining greater foothold in the recent years in Singapore.

With the rising number of green building construction projects, it is necessary to ensure that green building projects are completed on time and delivered successfully. A project is considered successful if it is completed on time, within budget and meeting the required quality standards specified by the client (Chan, Kumaraswamy 1996; Walker 1995). Furthermore, projects, in particular, that are completed on time are an indicator of an efficient construction industry (Male 1988). Positive construction time performance ensures that a project can be completed within the stipulated time or earlier. This will reduce the amount of overhead cost and provide a higher opportunity for the client to generate revenue at an earlier stage.

As green building construction continues to grow and gain popularity, there is a need to better understand schedule performance of green building construction projects. Comparing with traditional building projects, this study aims to: (1) investigate the degree of project delay in comparison between traditional and green projects; (2) analyze the causal factors of delay for both green and traditional projects; and (3) to discuss the possible solutions for the delay problems of green projects.

\section{Background}

\subsection{Green buildings}

The construction of green building is part of sustainable construction. According to Kibert (2008), sustainable construction addresses the ecological, social and economic issues of a building in the context of its community. Sustainable construction is applied throughout the entire life cycle of construction, from preconstruction to disposal of the building. Such construction aimed to reduce the impact of the construction practice on the environment through its planning and managing of a construction project complying with the contract document (Glavinich 2008; Pitt et al. 2008). 
In most literature, the term green building is defined as an environmentally sustainable building which is constructed with minimal environmental impacts. This is further supported by Glavinich (2008) who defined green building as a building that provides the required building performance criteria while minimizing disturbance to and improving the ecosystems in the local, regional and global context throughout its entire building life cycle. Green buildings are healthy facilities which are designed and built in a resource efficient manner using ecologically based principles (Kibert 2008).

\subsection{Green building construction industry}

Since the inception of Green Mark Scheme together with the 1st and 2nd Green Building Masterplan, Singapore has experienced a concerted shift towards the development of green buildings (Hwang, Ng 2013; Tobias 2010). The sharp growth in the number of BCA Green Mark Certified new buildings in 2007 is an evident success of the BCA's 1st Green Building Masterplan which was launched in 2006 (Building and Construction Authority 2009). The thrust towards more buildings being certified with Green mark has grown beyond Singapore to overseas such as Thailand, Vietnam, Indonesia, and China (BCA 2009). At present, statistics from the BCA green mark webpage revealed that there are a total of 326 green mark certified buildings in Singapore where 52 buildings are awarded with green mark platinum, 36 green mark goldplus certified, 134 green mark gold certified and 104 green mark certified buildings (BCA 2010).

According to BCA (2010), Green Mark provides a meaningful differentiation of buildings. The benefits of having a BCA Green Mark building include a reduction in water and energy bills; an improvement in indoor environmental quality for healthy living; and a reduction in potential negative impact on the environment. In addition, green building offers a reduction lifecycle costing in its operation and maintenance cost as well (Kats et al. 2003).

It is widely known that green building projects contributes to environmental sustainability and greater human health benefits to its occupants. Research has proven that with minimal increase in upfront cost of about $2 \%$ to incorporate green designs in building, it will result in lifecycle savings of $20 \%$ of total construction cost on an average which is more than ten times the initial investment (Kats et al. 2003). For that reason, it is worthy to consider the implementation of green building design as compared to traditional building design.

\subsection{Green building schedule performance}

It is important that green requirements are well addressed and reflected in project schedule to avoid any schedule delays. As noted by GreenBiz Group (2005) and Kats et al. (2003), design and construction process of green building construction usually takes longer than traditional building construction. This is due to the reason that project team members require more time to be familiar with and implement green building practices. Also, design documents are required to be more comprehensive before the start of construction, as more time is necessary for architectural and engineering designs to integrate green building practices into the project. This will have an impact on the project schedule and may increase design cost (Kats et al. 2003). 
In addition, green requirements have an effect on schedule of procurement, construction, and project closeout and commissioning (Glavinich 2008). Contractors have to ensure that local and imported materials used for green construction meet preset-standards and are delivered without delays. During construction, green requirements and constraints can have a great influence on the construction sequence and duration as well. For example, installation of HVAC ducts is mounted before the building under construction is enclosed while in green building construction, to prevent any dust and moisture contamination, the building is enclosed before installation of the ducts. As such, it can be seen that green requirement may pose an impact on construction schedule and such requirements are needed to be indicated in the schedule to prevent any problems causing delay.

\subsection{Factors causing project delay}

While completing projects on time is an indicator of efficiency, construction processes are subject to various and unpredicted factors that can cause delay (Assaf, Al-Hejji 2006). Construction delay was defined by Assaf and Al-Hejji (2006) as schedule overruns either beyond completion date specified in the contract, or beyond the date that the parties agreed upon for the delivery of the project. In today's construction industry, it is known that project delay is an international common problem (Assaf, Al-Hejji 2006; Chan, Kumaraswamy 1996; Hwang, Lim 2013; Hwang et al. 2013; Odeh, Battaineh 2002). In Australia, Bromilow (1974) found that only one-eighth of the building contracts were completed within the scheduled completion dates and the average construction time overrun exceeded by $40 \%$. Assaf and Al-Hejji (2006) identified that 70\% of the large projects in Saudi Arabia experience time overrun. It was found that the average time overrun of projects is between $10-30 \%$ of the original duration. In Hong Kong, Chan and Kumaraswamy (1995) observed that almost 70\% of the public and private building projects were completed behind schedule. Ogunlana et al. (1996) conducted a research on construction delay in Thailand and found that residential projects experienced an approximate of $34.33 \%$ delay from the original schedule and $11.33 \%$ for office buildings. In Malaysia, Sambasivan and Yau (2007) mentioned that about $17.3 \%$ of the 417 government contract projects were considered sick (more than 3 months of delay or abandoned) in 2005.

There are several studies (Mansfield et al. 1994; Chan, Kumaraswamy 1997; Nguyen et al. 2004; Walker 1995; Assaf, Al-Hejji 2006; Alaghbari et al. 2007; Sambasivan, Yau 2007; El-Razek et al. 2008; Choi 2009; Zhang 2011) that evaluated and classified the factors that affect project schedule and delay.

Based on the literature reviewed, this study identified 38 factors and grouped them into 8 major categories. More details of the factors and categories are discussed below and summarized in Table 1.

\subsubsection{Project related factors}

Factors in this category include the project delivery methods, the lack of communication between all the project team members, or the speed of decision making involving all projects teams. Chan and Kumaraswamy (1997) found that low speed of decision making involving all 
Table 1. Factors causing project schedule delays

\begin{tabular}{|c|c|c|c|c|c|c|c|c|}
\hline & \multirow[b]{2}{*}{ List of Factors } & \multicolumn{7}{|c|}{ Authors } \\
\hline & & 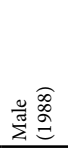 & 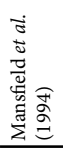 & 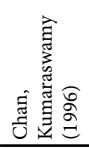 & 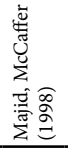 & 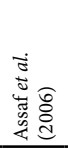 & 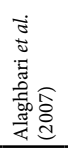 & 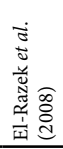 \\
\hline \multirow{5}{*}{$\begin{array}{l}\text { Project related } \\
\text { factors }\end{array}$} & Project delivery methods & $\mathrm{V}$ & & & & $\mathrm{V}$ & & \\
\hline & Project cost & & $\mathrm{V}$ & $\mathrm{V}$ & & & & $\mathrm{V}$ \\
\hline & Speed of decision making involving all project teams & $\mathrm{V}$ & & $\mathrm{V}$ & & & & \\
\hline & Communication/coordination between key parties & $\mathrm{V}$ & $\mathrm{V}$ & $\mathrm{V}$ & & & & $\mathrm{V}$ \\
\hline & Disputes/conflicts between key parties & & & $\mathrm{V}$ & & $\mathrm{V}$ & & \\
\hline \multirow{4}{*}{$\begin{array}{l}\text { Client related } \\
\text { factors }\end{array}$} & Speed of decision making by client & & & & & $\mathrm{V}$ & & $\mathrm{V}$ \\
\hline & Delay in progress payment by client & & & & $\mathrm{V}$ & $\mathrm{V}$ & & $\mathrm{V}$ \\
\hline & Client's level of experience in the construction industry & $\mathrm{V}$ & & & $\mathrm{V}$ & & & \\
\hline & Client initiated variation of works & $\mathrm{V}$ & & $\mathrm{V}$ & & $\mathrm{V}$ & & $\mathrm{V}$ \\
\hline \multirow{4}{*}{$\begin{array}{l}\text { Design team } \\
\text { related factors }\end{array}$} & Mistakes and delay in producing design documents & $\mathrm{V}$ & $\mathrm{V}$ & $\mathrm{V}$ & & $\mathrm{V}$ & & $\mathrm{V}$ \\
\hline & Level of design team experience & $\mathrm{V}$ & & $\mathrm{V}$ & & $\mathrm{V}$ & & \\
\hline & Complexity in project design & & & $\mathrm{V}$ & & $\mathrm{V}$ & & \\
\hline & Misunderstanding of client's requirements by design team & $\mathrm{V}$ & & & & $\mathrm{V}$ & & \\
\hline \multirow{5}{*}{$\begin{array}{l}\text { Consultant related } \\
\text { factors }\end{array}$} & Delay in performing inspection and testing & & $\mathrm{V}$ & $\mathrm{V}$ & & $\mathrm{V}$ & & $\mathrm{V}$ \\
\hline & Delay in approving major changes in the scope of works & & $\mathrm{V}$ & & & $\mathrm{V}$ & & $\mathrm{V}$ \\
\hline & Time for reviewing and approval of design documents by consultants & & & $\mathrm{V}$ & & $\mathrm{V}$ & & \\
\hline & Conflict between consultants and design engineers & & & & & $\mathrm{V}$ & & \\
\hline & Level of experience of consultants & & & & & $\mathrm{V}$ & $\mathrm{V}$ & \\
\hline \multirow{5}{*}{$\begin{array}{l}\text { Contractor related } \\
\text { factors }\end{array}$} & Poor site management and supervision & $\mathrm{V}$ & & $\mathrm{V}$ & & $\mathrm{V}$ & & \\
\hline & Contractor's deficiencies in planning and updating schedule plans & & & $\mathrm{V}$ & & $\mathrm{V}$ & & $\mathrm{V}$ \\
\hline & Difficulties in financing project by contractors & & $\mathrm{V}$ & & & $\mathrm{V}$ & $\mathrm{V}$ & \\
\hline & Construction methods implemented by contractors & & $\mathrm{V}$ & & & $\mathrm{V}$ & & \\
\hline & Rework due to defects during construction & & $\mathrm{V}$ & & & $\mathrm{V}$ & $\mathrm{V}$ & $\mathrm{V}$ \\
\hline \multirow{3}{*}{$\begin{array}{l}\text { Labor related } \\
\text { factors }\end{array}$} & Shortage of labor & & & $\mathrm{V}$ & & $\mathrm{V}$ & & \\
\hline & Low labor productivity & & & $\mathrm{V}$ & & $\mathrm{V}$ & & $\mathrm{V}$ \\
\hline & Unskilled labor & & & $\mathrm{V}$ & $\mathrm{V}$ & & $\mathrm{V}$ & \\
\hline \multirow{7}{*}{$\begin{array}{l}\text { Equipment/ } \\
\text { material related } \\
\text { factors }\end{array}$} & Equipment breakdown & & & $\mathrm{V}$ & $\mathrm{V}$ & $\mathrm{V}$ & & \\
\hline & Unskilled operators & & & & & $\mathrm{V}$ & & $\mathrm{V}$ \\
\hline & Low productivity and efficiency of equipment & & & $\mathrm{V}$ & & $\mathrm{V}$ & & $\mathrm{V}$ \\
\hline & Lack of high technology mechanical equipment & $\mathrm{V}$ & & & & $\mathrm{V}$ & & \\
\hline & Availability of material & & $\mathrm{V}$ & $\mathrm{V}$ & & $\mathrm{V}$ & $\mathrm{V}$ & $\mathrm{V}$ \\
\hline & Changes in materials during construction & & & $\mathrm{V}$ & & $\mathrm{V}$ & & $\mathrm{V}$ \\
\hline & Imported materials & & $\mathrm{V}$ & & & & & \\
\hline \multirow{6}{*}{ External factors } & Unforeseen ground conditions & $\mathrm{V}$ & $\mathrm{V}$ & $\mathrm{V}$ & & $\mathrm{V}$ & & $\mathrm{V}$ \\
\hline & Unfavourable weather condition on construction activities & & $\mathrm{V}$ & & & $\mathrm{V}$ & & $\mathrm{V}$ \\
\hline & Accidents during construction & & & & & $\mathrm{V}$ & & $\mathrm{V}$ \\
\hline & Changes in government regulations and law & & & & & $\mathrm{V}$ & $\mathrm{V}$ & \\
\hline & Delay in performing final. inspection and certification by third party & & & & & $\mathrm{V}$ & & \\
\hline & Delay in obtaining permits from political units/body of officials & $\mathrm{V}$ & & & & $\mathrm{V}$ & & $\mathrm{V}$ \\
\hline
\end{tabular}

project teams is the third most significant factor that caused project schedule delay. The right selection of project delivery methods can reduce defective design, and improve coordination between project members, ultimately enhancing project schedule performance and preventing project delay (Eriksson, Westerberg 2011).

\subsubsection{Client related factors}

Clients play an important role in construction projects. The client is one of the key drivers to ensure that a project is completed successfully (Thompson 1991). From the research conducted by Assaf and Al-Hejji (2006), client related factor category was ranked first with regard to the impact on schedule delay. Client initiated variation in this category was deemed as one of the top five most significant delay factors across numerous studies. Bromilow (1974) found 
that clients contributed to $41 \%$ to the overall variations in projects. Client initiated variation was identified as the fourth important cause of delays by Chan and Kumaraswamy (1996). Furthermore, the financial issues caused by clients were considered the main cause of delay by Ahmed et al. (2003) and Abdul-Rahman et al. (2011).

\subsubsection{Consultant related factors}

Consultants such as project managers and engineers hold great responsibilities in the project. Consultant related factor category was ranked third in the study by Assaf and Al-Hejji (2006). It was specified that consultants should review and approve design documents timely prior to construction phase to avoid any delay.

\subsubsection{Design team related factors}

Researchers found differing perceptions on the relative impact of schedule delay by the various project team members. Nonetheless, design team related factor was deemed as the most influential factor category on project delay by the contractors in the studies by Chan and Kumaraswamy (1997) and Assaf and Al-Hejji (2006).

\subsubsection{Contractor related factors}

Alaghbari et al. (2007) studied the significant factors causing delay of building construction projects in Malaysia and had identified that the contractor related factors were first in rank. This was further supported by the research conducted by Chan and Kumaraswamy (1996). Therefore, main factors attributed by contractor which pose great impact on the project schedule consist of the contractor's financial capability to finance the project and the ability to manage and supervise the construction site properly.

\subsubsection{Labor related factors}

Labor related factors were identified as the top 10 factors affecting project schedule in research by El-Razek et al. (2008), Arditi et al. (1985), Mansfield et al. (1994) as well as by Assaf and Al-Hejji (2006).

\subsubsection{Equipment and materials related factors}

Shortage of equipments and/or materials can cause severe stoppage of work leading to project delay. Late delivery of material and plants factor was ranked the highest in a research conducted by Majid and McCaffer (1998). Similarly, materials and equipment related factors affecting schedule was second in rank as investigated by El-Razek et al. (2008).

\subsubsection{External factors}

External related factors especially unforeseen ground conditions was rated as the top 3 most significant factors affecting project schedule by Chan and Kumaraswamy (1996). Unexpected ground conditions include poor soil condition, underground obstruction, 
hard rock barriers and inaccurate estimation of groundwater flow. This might be due to the fact that most projects were rushed into commencement, which resulted in inadequate feasibility studies (Mansfield et al. 1994).

\subsection{Implications}

Although there have been several researches carried out to evaluate schedule performance of traditional construction projects, there is limited literature that has explored schedule performance of green building construction projects. Similarly, the factors causing schedule delay of green projects have been rarely studied. Therefore, there is a need to examine project schedule performance of green building projects, identifying various factors that cause the delay of these projects.

\section{Methodology and data presentation}

To achieve the objectives of this study, a comprehensive literature review was first conducted. After gaining an understanding of green building construction and its progress in the construction industry as well as the factors that cause project schedule delays, it was recognized that input from industry practitioners are needed in order to ensure that this study can represent the overall green building construction position. As a result, a survey questionnaire was developed.

The findings from the literature review supported the development of the questionnaire that consisted of four sections capturing: (1) the profile of the participating companies and respondents (2) the information of traditional and green building projects performed by the companies; (3) the factors causing schedule delays; and (4) the solutions for improving green building schedule performance. The questionnaires were sent out via email to construction, consulting, development, and quantity surveying companies registered in the directories of BCA and Singapore Institute of Surveyors and Valuers. As the BCA green mark scheme commenced in 2005, the target of the survey was the companies that had experience in both green and traditional projects performed in years of 2005 to 2010 .

Using the data obtained from the survey, analyses on frequency, descriptive mean scores, and Spearman's ranked correlations were performed to determine the degree of schedule delays in traditional and green building construction projects as well as the relative association of the ranking of different factors causing delays. The respondents were asked to provide the total number of traditional projects they performed for the last five years, followed by the numbers of the projects that had experienced schedule delays. For the green building projects, the respondents provided the same. Also, the respondents selected an appropriate rating based on a defined scale to reflect on the importance level of each of the listed factors. The scale was based on a five-point Likert scale with ' 1 ' being 'not important' and ' 5 ' being 'very important'. Similarly, the five-point Likert scale was also used to evaluate the effectiveness of the recommended solutions to improve green building project schedule performance.

In addition, the Spearman rank correlations were calculated and tested to see if the relative importance of the factors affecting delays of green building projects is significantly 
Table 2. Profile of companies and respondents

\begin{tabular}{|c|c|c|c|c|c|c|c|c|c|c|}
\hline & \multirow{3}{*}{ Characteristics } & \multicolumn{8}{|c|}{ Years of experience } & \multirow{3}{*}{$\begin{array}{c}\text { Total } \\
(\mathrm{N}=30)\end{array}$} \\
\hline & & \multicolumn{2}{|c|}{1 to 2 years } & \multicolumn{2}{|c|}{2 to 3 years } & \multicolumn{2}{|c|}{3 to 4 years } & \multicolumn{2}{|c|}{$>4$ years } & \\
\hline & & C.I & G & C.I & G & C.I & G & C.I & G & \\
\hline \multirow{5}{*}{ Company } & Construction & 0 & 2 & 0 & 3 & 0 & 4 & 18 & 9 & $18(60 \%)$ \\
\hline & Consulting & 0 & 0 & 0 & 0 & 0 & 1 & 5 & 4 & $5(16.67 \%)$ \\
\hline & Development & 0 & 0 & 0 & 0 & 0 & 1 & 3 & 2 & $3(10 \%)$ \\
\hline & Quantity Surveying & 0 & 0 & 0 & 0 & 0 & 0 & 4 & 4 & $4(13.33 \%)$ \\
\hline & Total & $0(0 \%)$ & $2(6.67 \%)$ & $0(0 \%)$ & $3(10 \%)$ & $\mathbf{0 \%}$ & $6(20 \%)$ & $30(100 \%)$ & $20(63.33 \%)$ & $30(100 \%)$ \\
\hline \multirow{4}{*}{ Respondent } & $\begin{array}{l}\text { Project Manager/ } \\
\text { Construction Manager }\end{array}$ & 0 & 3 & 0 & 3 & 0 & 5 & 18 & 7 & $18(60 \%)$ \\
\hline & $\begin{array}{l}\text { Project Director/ } \\
\text { Higher Management }\end{array}$ & 0 & 0 & 0 & 1 & 0 & 3 & 4 & 0 & $4(13.33 \%)$ \\
\hline & Project Personnel & 0 & 0 & 0 & 1 & 1 & 2 & 7 & 5 & $8(26.67 \%)$ \\
\hline & Total & $0(0 \%)$ & $3(10 \%)$ & $0(0 \%)$ & $5(16.67 \%)$ & $1(3.33 \%)$ & $10(33.33 \%)$ & $29(96.67 \%)$ & $12(40 \%)$ & $30(100 \%)$ \\
\hline
\end{tabular}

C.I refers to years of experience in construction industry;

$\mathbf{G}$ refers to years of experience in green building construction;

Higher Management includes Executive president, Project Director, General Manager and Managing Director; Project Personnel includes Project Engineers, Construction Engineers, and Quantity Surveyors.

correlated with that of traditional construction projects. The test was performed at the confidence level of 0.05 .

As a result of the survey, 30 completed questionnaires were returned. A summarized profile of the companies and respondents that participated in the survey is presented in Table 2.

\section{Data analysis and discussions}

\subsection{Comparison of schedule delays}

The companies were asked to input the number of traditional and green building projects that they had performed as well as the number of projects delayed. The analysis further broke down the projects based on project type, nature and size to understand how the characteristics of projects affect the project schedules.

As seen in Table 3, the overall percentage of projects that had been delayed were $15.91 \%$ and $32.29 \%$ for traditional and green building projects respectively. It can be inferred that green building construction projects have a higher probability of delays as compared to traditional building projects. As green building construction projects require green technologies which are still relatively new to the industry, it requires more time to understand and incorporate these technologies into the design. This is further supported by Snell and Callahan (2005) as they pointed out that green building construction takes much longer to complete and presents more challenges than anticipated even if builders are highly experienced at construction, design and creative problem-solving.

In terms of specific project type, commercial building projects accounted for the highest frequency of delay for both the traditional (25.00\%) and green (57.14\%) building projects. 
Table 3. Project delay: traditional vs. green building projects

\begin{tabular}{|c|c|c|c|c|c|c|c|}
\hline Characteristics & & $\begin{array}{c}\text { (a) No. of } \\
\text { Traditional Projects } \\
\text { Performed }\end{array}$ & $\begin{array}{c}\text { (b) No. of } \\
\text { Projects Delayed } \\
\text { among (a) }\end{array}$ & $\begin{array}{l}\text { Percentage } \\
\text { Delayed }\end{array}$ & $\begin{array}{l}\text { (c) No. of } \\
\text { Green Projects } \\
\text { Performed }\end{array}$ & $\begin{array}{l}\text { (d) No. of } \\
\text { Projects Delayed } \\
\text { among (c) }\end{array}$ & $\begin{array}{l}\text { Percentage } \\
\text { Delayed }\end{array}$ \\
\hline \multirow{3}{*}{ Project Type } & Commercial & 48 & 12 & $25.00 \%$ & 28 & 16 & $57.14 \%$ \\
\hline & Residential & 91 & 9 & $9.89 \%$ & 21 & 0 & $0.00 \%$ \\
\hline & Educational & 81 & 14 & $17.28 \%$ & 47 & 15 & $31.91 \%$ \\
\hline \multirow{2}{*}{ Project Nature } & New Construction & 184 & 32 & $17.39 \%$ & 93 & 31 & $33.33 \%$ \\
\hline & Addition \& Alteration & 36 & 3 & $8.33 \%$ & 3 & 0 & $0.00 \%$ \\
\hline \multirow{7}{*}{ Project Size } & Less than $\$ 5 \mathrm{M}$ & 32 & 4 & $12.50 \%$ & 3 & 1 & $33.33 \%$ \\
\hline & $\$ 5 \mathrm{M}$ to less than $\$ 10 \mathrm{M}$ & 6 & 0 & $0.00 \%$ & 8 & 2 & $25.00 \%$ \\
\hline & $\$ 10 \mathrm{M}$ to less than $\$ 20 \mathrm{M}$ & 35 & 5 & $14.29 \%$ & 6 & 0 & $0.00 \%$ \\
\hline & $\$ 20 \mathrm{M}$ to less than $\$ 30 \mathrm{M}$ & 33 & 0 & $0.00 \%$ & 13 & 3 & $23.08 \%$ \\
\hline & $\$ 30 \mathrm{M}$ to less than $\$ 40 \mathrm{M}$ & 15 & 1 & $6.67 \%$ & 16 & 5 & $31.25 \%$ \\
\hline & $\$ 40 \mathrm{M}$ to less than $\$ 50 \mathrm{M}$ & 27 & 4 & $14.81 \%$ & 18 & 7 & $38.89 \%$ \\
\hline & $\$ 50 \mathrm{M}$ and Above & 72 & 21 & $29.17 \%$ & 32 & 13 & $40.63 \%$ \\
\hline All Projects & & 220 & 35 & $15.91 \%$ & 96 & 31 & $32.29 \%$ \\
\hline
\end{tabular}

This may be due to the fact that commercial projects are relatively unique in nature and vary widely in terms of requirements, design and specifications when compared to residential or educational buildings that can be easily modeled based on past projects. In comparison between the percentage of delay in traditional and green building projects, the percentage of delay for green commercial projects (25\%) was more than twice of traditional commercial building projects (57.14\%). One possible reason for a higher delay occurrence in green commercial building projects may be the complexity in incorporating green technologies into the building systems.

Table 3 also presents the percentage of projects that were delayed by project nature, namely, new construction and addition/alteration. It can be seen that more new construction projects were delayed than addition and alteration projects for both traditional and green building projects. This result could be expected as new construction projects have higher level of uncertainty attributed by the wider scope of the projects than that of addition and alteration projects. It is also observed that new green building construction $(33.33 \%)$ may encounter the higher likelihood of delay than traditional building construction (17.39\%). As the green building construction is still relatively new to the construction industry, it may be more difficult for the players in the industry to manage this type of green building projects.

Furthermore, large-sized projects in terms of contract amount had a higher tendency to encounter project delay. The projects costing $\$ 50$ million and above reported the highest percentage of delay for both traditional $(29.17 \%)$ and green projects (40.63\%). With more project parties involved in large construction projects, relationships and flow of information among project team members become more complicated, and inadequate and ineffective coordination can increase the likelihood of communication breakdown and variations, leading to project delay (Nguyen et al. 2004). Large green building projects, in particular, may require more effective coordination and collaborators than traditional projects due to the complexity inherent in usages of new processes and technologies, and this aspect is reflected at the analysis result. 


\subsection{Factors affecting project schedule delays}

Having investigated the degree of project delay occurred in traditional and green building projects, it became apparent that identifying various factors responsible project delay is necessary to improve schedule performance. As a result, the relative importance of the factors regarded by the respondents as major causes of project delay was analyzed for traditional and green building projects. The analysis results are presented in Table 4.

\subsubsection{Project related factors}

Under traditional building projects, factor P4 yields the highest mean score of 4.53 as seen from Table 4. It can be interpreted that the respondents considered communication and coordination between key parties as the upmost important factor that will affect the project schedule to a large extent. Since factor P3 with mean score of 4.53 is relatively close to the mean score of factor $\mathrm{P} 4$, it can also be derived that the speed of decision making involving all project teams is also a critical factor that may affect the project schedule. Factors P1 and P2 are ranked an average of close to a mean of 4.0 showing a degree of importance as well. However, factor P5 has the lowest rank of mean score 3.17 which signified that legal disputes and conflicts between key parties weighs a small percentage of importance that may affect the project schedule.

For green building construction project, the most influential factor which may cause delay in project schedule is attributed by factor P3 with a high means score of 4.77 . Although factor $\mathrm{P} 4$ is second in rank with mean score of 4.70 , the close mean score between the two factors illustrates that factor $\mathrm{P} 4$ is as important as factor P3. Similar to traditional projects, $\mathrm{P} 1$ and $\mathrm{P} 2$ are ranked with an average of 4.30, while factor P5 is lowest in rank denoting that it has the lowest impact on project schedule.

The $3 \mathrm{rd}$, 4th and 5 th rank of the factors under the project related factors between traditional and green building projects are consistent. In contrast, the first and second rank of the project related factors for the two groups are inverted. Since the top two factors between traditional and green building projects have mean score of more than 4.5 , it can be implied that communication/ coordination between key parties is required to ensure that decisions making between key parties can be determined promptly to avoid project delay.

To further examine the agreement of the ranking of the project related factors between traditional and green building projects, the spearman's correlation coefficient of 0.895 was obtained. This shows a positive correlation between the ranking of the project related factors under traditional and green building projects since a high value of rank correlation coefficient suggests a strong agreement between the two groups. Since the p-value of 0.04 at $95 \%$ significance level is less than the significance, $\alpha=0.05$, this shows that there is significant relationship between the traditional and green building projects for factors that are project related. Agreement between the rankings of the factors for both groups is observed as the respondents may feel that the extent of effect by the individual factors is similar for both traditional and green building projects. 


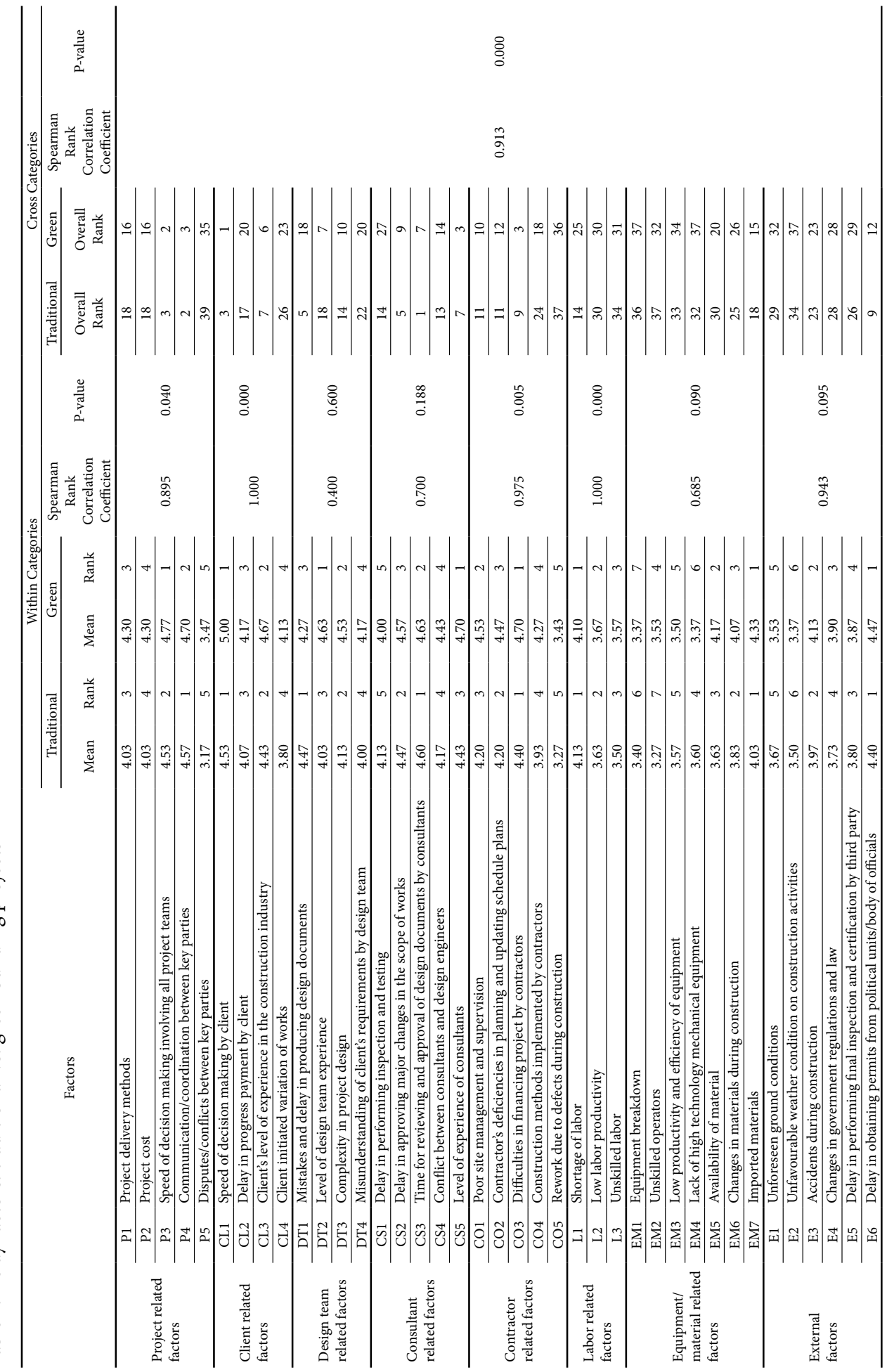




\subsubsection{Client related factors}

With reference to Table 4, the ranking of client related factors between traditional and green building projects is identical. Respondents agreed that the speed of decision making by client has the highest effect on schedule delay in this category. Factor CL3 with mean scores of above 4.5 for both traditional and green projects suggest that it has considerable effect on project schedule as well. Therefore, to ensure positive schedule performance, the client's speed on decision making and level of experience is vital to ensure that the schedule is without delay.

Under green building projects, all the client related factors have mean scores which are above 4.00. This illustrates the fact that the client's impact on schedule is of great magnitude and should not be overlooked.

The Spearman's rank correlation coefficient of 1.00 indicates a positive correlation between the two groups. Since the p-value of 0.000 at $95 \%$ significance level is less than the significance, $\alpha=0.05$, it implies that there is a strong agreement in the ranking of the factors under the client related categories. There is strong agreement on the rankings of the impact of the factors affecting project schedule under the two groups as the level of client involvement might be similar for the two types of projects. It might also be due to the fact that each factor has equal impact on traditional and green project schedule.

\subsubsection{Design team related factors}

Factor DT1 has the highest ranked mean of 4.47 under traditional building projects. It is followed by factor DT3, DT2 and DT4 respectively. Amongst all the design team related factors, mistakes and delay in producing design document has the highest influence in causing the project schedule to be delayed. For green building projects, factor DT2 with mean score of 4.63 is ranked the highest with factor DT3, DT1 and DT4 ranked behind in accordance. Level of design team experience is top in rank under green building projects as team members should be familiar with the specifications of green technology when it is incorporated into the design of the building systems.

The Spearman's rank correlation coefficient of 0.20 indicates a weak correlation between the two groups. In addition, since the p-value of 0.600 at $95 \%$ significance level is more than the significance, $\alpha=0.05$, it implies that there is no significant relationship and insubstantial agreement in the ranking of the factors under the client related category between the two groups. As such, we can conclude that the severity of the factors varies according to traditional and green building projects.

The disparity of the ranking between the two groups may be because more emphasis is placed on the design of green building construction project. According to Kubba (2010), green buildings are progressively incorporating more advanced and intricate systems of interacting elements. During design, the impact of the elements on each system must be considered as a whole. A failure to take into account the integration of green technologies and its impact on other building elements would result in construction conflicts leading to delay to address such problems. As such, the levels of experience of the design team as well as complexity of the design have the highest impact on green building project schedule as compared to traditional building project. 


\subsubsection{Consultant related factors}

Under traditional building projects, factor CS3 of mean 4.60 is ranked first, followed by factor CS2, CS1 and CS4 correspondingly. Factor CS5 of mean 4.70 is considered to have the highest impact on green project schedule amongst all the consultant related factors. It is similar to that of design team related factors for green building projects, where level of design team experience is considered the factor with the highest impact on project schedule delay.

The Spearman's rank correlation coefficient of 0.70 indicates a fairly strong correlation between the two groups. However, the p-value of 0.188 at $95 \%$ significance level is more than the significance, $\alpha=0.05$. It implies that there is insufficient agreement and relationship on the ranking of the factors between the two groups although the rank correlation coefficient is relatively strong. As such, it is deduced that the severity of the factors varies according to traditional and green building projects.

Level of experience of the consultant team is important under green building construction projects as the level of design complexity is higher as compared to traditional building projects. With reference to Kubba (2010), specialist consultants should be involved in the design process earlier to incorporate their suggestions and requirements in the design such that that their contributions are taken into account to safeguard maximum efficiency. Therefore, without the required level of knowledge and experience by the consultants, the harmonization of the systems would not be possible and risk the chances of having conflicts. In addition, a delay in reviewing and approving the design would further impede the project schedule.

\subsubsection{Contractor related factors}

With reference to Table 4, factor CO3 is deemed as the most influential factor on project schedule delay for both traditional and green building projects. The mean score of factor $\mathrm{CO} 3$ under traditional building project is found to be 4.40 and 4.70 under green building projects. Factor $\mathrm{CO} 1$ and $\mathrm{CO} 2$ are ranked second and third interchangeably for both groups as seen in Table 4. It is noted that aside from the incapability of financing the project which would cause the project schedule to be delayed, good site management and supervision accompanied by the ability to plan and monitor project schedule appropriately is vital to ensure that optimal project schedule performance is met.

The Spearman's rank correlation coefficient of 0.90 indicates a strong correlation between the two groups. As, the p-value of 0.005 at $95 \%$ significance level is less than the significance, $\alpha=0.05$, it indicates that there is adequate agreement and significant relationship on the ranking of the level of impact of the contractor related factors between traditional and green building projects. Similar rankings on the level of impact of the contractor related factors for both green and traditional projects as it is perceived that the degree of influence of the variables associated with contractor is unaffected by the type of project.

\subsubsection{Labor related factors}

In this category, the statistics showed that there is unanimous agreement by the respondents on the level of impact between the three factors on traditional and green building projects. Factor L1 is regarded as having the highest impact on project schedule for both traditional and green building projects, while factor L2 and L3 are ranked second and third respectively. 
The Spearman's rank correlation coefficient of 1.00 indicates a perfect linear correlation between the two groups. With the p-value of 0.00 at $95 \%$ significance level is more than the significance, $\alpha=0.05$, it suggests that there is significant relationship between the ranking of the factors under both the green and traditional building projects. There is strong agreement on the rankings of the impact by the labour related factors affecting project schedule as the influence might be comparable under the two types of projects.

\subsubsection{Equipment and material related factors}

As seen in Table 4, both traditional and green building projects have ranked factor EM7 as the highest most severe factor which may cause a project schedule delay under this category. Imported materials are long lead items which require a great number of weeks or months to be delivered on site. As such, any technical hitch on the delivery of imported materials especially when it concerns the critical activities in a schedule would cause adverse impact on the project leading to a delay. With reference to Table 4 , majority of the factors have mean score less than 4.0 which implies that equipment and material related factors have relatively less impact on project schedule as compared to other categories. This might be due to the fact that equipment and material related factors can be better controlled and predicted in contrast with other categories.

The Spearman's rank correlation coefficient of 0.714 indicates a strong correlation between the two groups. As, the p-value of 0.090 at $95 \%$ significance level is more than the significance, $\alpha=0.05$, this indicates that there is insignificant relationship and agreement on the ranking of the factors between the two groups.

Disagreement on the rankings of the equipment and material related factors is observed between traditional and green building projects as this might be due to the fact that green technologies are usually imported from overseas. Therefore, the availability and delivery of these technologies is of higher importance (2nd in rank) than traditional building projects (3rd in rank). Low level of equipment-operator skill is ranked forth under green building projects; while it is sixth in rank under traditional building projects. It is attributable to the reason that green building construction projects require extensive knowledge and experience to incorporate the green technologies into the building design and during construction. As such, higher emphasis is place on the skill of the operator to construct and integrate the green technologies with the other building systems.

\subsubsection{External related factors}

Factor E6 is first in the rank with mean 4.40 and 4.70 for traditional and green building projects respectively. The high mean scores of factor E6 which are around 4.5 for both groups imply that any impediment in obtaining permits from political units/body of official will likely place the project to experience a project schedule delay. The ranking of factors between the two groups are relatively similar expect for the third and fourth ranked factors.

The Spearman's rank correlation coefficient of 0.943 indicates a strong correlation between the two groups. As, the p-value of 0.005 at $95 \%$ significance level is less than the significance, $\alpha=0.05$, this suggest that there is ample agreement and significant relationship on the ranking of the factors between the two groups. 
It can be observed that there is agreement on the rankings of impact of the external related factors for both green and traditional projects. This might be because external factors are more unpredictable and it is hard to gauge whether there might be any difference on the degree of impact on the project schedule for different types of project. Therefore, it is assumed that the level of effect is comparative for traditional and green building projects.

\subsubsection{Rank for all factors}

The top 10 most significant delay factors for traditional building projects as identified in the survey were in sequence of CS3, P4, CL1, P3, DT1, CS2, CL4, CS5, E6, and CO3. Under green building projects, the 10 most significant delay factors are CL1, P3, CO3, CS5, P4, CL4, CS3, DT2, CS2, and DT1.

The Spearman's rank correlation coefficient value of 0.913 indicates a strong correlation between the two groups. As, the significance value $=0.000$ at $95 \%$ significance level is less than the significance, $\alpha=0.05$, this suggest that there is ample agreement and significant relationship on the ranking of the factors between the two groups.

The common top three most important factors which have the greatest effect on project schedule delay for both green and traditional building projects are (1) Speed of decision making by client, (2) Speed of decision making involving all project teams, and (3) Communication/ coordination between key parties.

The speed of decision making by client was ranked first under traditional building projects, and third under green building construction projects. The speed of decision by client is considered one of the most significant factors as key decisions are ultimately made by the client. Any delay in decision making from the client, especially when the decisions have a strong impact on activities which lie on the critical path, it will impinge on the project progress and schedule.

Speed of decision making involving all project teams was ranked second for traditional building projects, and third under green building projects. It is essential that effective decisions should be taken at the right time. To achieve a successful project, the flow of information between all project team members should be systematic and timely, addressing to the appropriate personnel. In addition, key decision makers should be clearly identified to warrant effective decision making.

Communication and coordination between key parties was identified as another major factor by the respondents. Under green building projects, it was ranked second, while it was fifth in rank under traditional building projects. From the study done by Chalabi and Camp (1984), it is learnt that inadequate communication between project team members was a critical factor causing delays, which impede project progress leading to problems in the project coordination and schedule. Communication and coordination between key parties have a greater effect on schedule delay in green building projects due to the fact that green building construction projects requires a more holistic and integrated approach as the design process is more complex and much of the design phases overlap with the construction phases (Glavinich 2008). As such, green building projects requires more effort in communicating amongst the various team members (Kibert 2008). 
In Table 4, the mean scores of each factor category were computed by taking an average of the mean scores of all the factors under the category. After which, the mean scores for each category are ranked.

The Spearman's rank correlation coefficient of 0.976 signifies a strong correlation between traditional and green building projects. As, the p-value of 0.000 at $95 \%$ significance level is less than the significance, $\alpha=0.05$, this suggest that there is strong agreement and significant relationship on the ranking of the factors between the two groups.

As seen from Table 4, there is substantial similarity between the top 3 factor categories which are deemed to have the highest impact on project schedule delay for both traditional and green building projects. The top 3 factor categories having the greatest influence on project schedule delay include (1) Client related factor, (2) Consultant related factor, and (3) Design team related factor.

Client, consultants and design team related factors were regarded to have the greatest impact on project schedule delay as it was agreed by most respondents that the planning and feasibility stage together with design stage were the two most important stages that determined the project schedule performance of the project. This was due to the fact that if the two stages were well planned and prepared, the design documents, such as drawings and specifications would be more complete and encompass all the requirements of client. As such, conflicts and changes can be prevented thus making it possible for the project to complete on time or ahead of as planned schedule (Al-Momani 2000). In accordance, without progress payment paid on time to contractors by the client, it vitiated the contractors' competency to finance the work and clients should minimize variations to ward off delays (Assaf et al. 1995).

\subsection{Solutions for improving green building project schedule performance}

The survey inquired about the respondents' sentiment in identifying possible recommendations to enhance green building construction project schedule performance. A total of 14 possible solutions were listed in the survey as shown in Table 5 and respondents selected top 5 solutions. The findings from the survey can be used to identify areas and aspects that should first be focused in order to reduce and prevent the factors causing delay of green building construction projects. Table 5 depicts ranking of the solutions based on the frequency of top 5 selected recommendations by the respondents.

Based on the result, the top 3 ranked solutions are discussed as follows:

- Ensure that the actual construction schedule and resources are seriously monitored and reviewed so that the performance is in line with as planned to avoid chances of cost overrun and disputes. Project managers should check that the green building construction planning and scheduling are in perpetual processes during construction and the schedule plans correspond with the time to develop the work and resources to prevent cost overrun and disputes (Assaf et al. 1995). To ensure that the project schedule and resources are constantly monitored and reviewed, owners may deploy certain tools and techniques for schedule control. A schedule control system may be set up to define the procedures when changes occur in the project schedule, and performance measurements should be carried out to assess the degree of variations that took place (Project Management Institute 2004). 
Table 5. Solutions for improving green building project schedule performance

\begin{tabular}{|c|c|c|c|}
\hline $\begin{array}{l}\text { Solutions for Schedule Improvement } \\
\text { of Green Buildings }\end{array}$ & $\begin{array}{l}\text { Frequency of } \\
\text { Top } 5 \text { Selected }\end{array}$ & Percentage & Rank \\
\hline $\begin{array}{l}\text { Ensure that the actual construction schedule and resources are seriously } \\
\text { monitored and reviewed so that the performance is in line with as planned } \\
\text { to avoid the chances of cost overrun and disputes }\end{array}$ & 23 & $76.67 \%$ & 1 \\
\hline $\begin{array}{l}\text { Check for mistakes and discrepancies in design documents to avoid redoing } \\
\text { of designs and drawing before submission for approval to avoid variations } \\
\text { or necessary corrections }\end{array}$ & 19 & $63.33 \%$ & 2 \\
\hline $\begin{array}{l}\text { Alternative procurement method should be analysed to ensure it meets the } \\
\text { project requirements and complexity }\end{array}$ & 16 & $53.33 \%$ & 3 \\
\hline Ensure that design documents are produced on time & 14 & $46.67 \%$ & 4 \\
\hline $\begin{array}{l}\text { Ensure that there is optimum number of labours to be assigned for individual } \\
\text { activities and motivate the workers to increase productivity }\end{array}$ & 14 & $46.67 \%$ & 5 \\
\hline $\begin{array}{l}\text { Pay progress payment to the contractor timely to facilitate the contractors' } \\
\text { ability to finance the work }\end{array}$ & 12 & $40.00 \%$ & 6 \\
\hline To minimize variation orders to avoid delays & 11 & $36.67 \%$ & 7 \\
\hline $\begin{array}{l}\text { Contractor should manage his financial resources and plan cash flow by } \\
\text { utilizing progress payment }\end{array}$ & 7 & $23.33 \%$ & 8 \\
\hline $\begin{array}{l}\text { Avoid delay in when reviewing and approval of documents, materials or } \\
\text { others are needed }\end{array}$ & 6 & $20.00 \%$ & 9 \\
\hline $\begin{array}{l}\text { Ensure that contractor have the capability and the resources for constructing } \\
\text { the project before awarding the tender }\end{array}$ & 4 & $13.33 \%$ & 10 \\
\hline $\begin{array}{l}\text { Administrative and technical staff should be appointed as soon as project } \\
\text { is awarded to facilitate the project is completed within specified time with } \\
\text { the required quality and estimated cost }\end{array}$ & 4 & $13.33 \%$ & 11 \\
\hline $\begin{array}{l}\text { Consultants should not delay the checking, reviewing and approving } \\
\text { of design documents leading to a delay in construction phase }\end{array}$ & 3 & $10.00 \%$ & 12 \\
\hline $\begin{array}{l}\text { Consultant should be flexible in evaluating contractors work and balance } \\
\text { between the required quality with cost }\end{array}$ & 3 & $10.00 \%$ & 13 \\
\hline $\begin{array}{l}\text { Contractor should carry out a comprehensive economic analysis and } \\
\text { workable financial plans }\end{array}$ & 3 & $10.00 \%$ & 14 \\
\hline
\end{tabular}

- Check for mistakes and discrepancies in design documents to avoid redoing of designs and drawing before submission for approval to avoid variations or necessary corrections. When mistakes and discrepancies are discovered in design documents, redoing of designs and drawing requires extra time beyond the as-planned schedule to make the necessary changes (Assaf et al. 1995) and it will more often than not lead to poor time performance (Chan, Kumaraswamy 1996). When these mistakes and discrepancies are detected especially during the construction stage, variations leading to rework may take place thus giving rise to redundant work with additional cost pumped in to make the corrections.

- Alternative procurement method should be analysed to ensure it meets the project requirements and complexity. Every procurement method has a different course of project development and involves different relationships between all the project team members (Nofera, Korkmaz 2010). As such, clients should analyse the project characteristics with care to select the appropriate procurement method as misinterpretation of project characteristics would 
probably lead to poor project performance and resulting in cost growth (Council 2003). Due to the higher complexity of technical systems used in green building construction projects, the projects requires high levels of interdependency, communications and close partnerships with all the project participants during design stages (Kibert 2008; Magent et al. 2009). In addition, research had also shown that early involvement of owners would enable green building construction projects to achieve its green objectives at lower cost (Beheiry et al. 2006; Lapinski et al. 2006). Accordingly, it is vital to analyse alternative procurement methods to achieve better green building construction project performance.

\subsection{Limitations}

One of the limitations of the analyses performed above was the small sample size. With a higher response rate, it would be able to project a more accurate industrial perspective with regards to the current green construction schedule performance in comparison with traditional building construction projects. In addition, the analyses were performed based on consultants' and contractors' point of view as the client/developers of past green construction projects declined to respond to the research survey.

\section{Conclusions and recommendations}

While Singapore has earned recognition for its efforts in promoting a green built environment, the Building and Construction Authority (BCA) decided to turn upward its goal of greening, aiming to have at least $80 \%$ of Singapore's buildings Green Mark certified by 2030 . Since all new building construction projects in Singapore are obliged to comply with Green Mark Scheme standards, it is therefore essential to look into how green building construction project performance can be managed more effectively.

The objectives of this study were: (1) investigate the degree of project delay in comparison between traditional and green projects; (2) analyze the causal factors of delay for both green and traditional projects; and (3) to discuss the possible solutions for the delay problems of green projects. The analysis on the survey results established that about $16 \%$ of the traditional building projects were delayed while about $32 \%$ of the green building projects were completed behind schedule. Furthermore, the top 5 critical factors that caused delay in green building projects were reported as (1) speed of decision making by client; (2) speed of decision making involving all project teams; (3) communication/coordination between key parties; (4) level of experience of consultants; and (5) difficulties in financing project by contractors.

The delay statistics in this study offers a benchmark for the industry to gauge the overall time duration required by green building construction projects as compared to traditional building projects. Similarly, Clients should take into consideration the additional time when setting out the overall project schedule for green building projects. In addition, the main factors that had significant impact on green building projects time performance in this research bring forth a focal point for project managers to enhance its performance for the project.

For future studies, construction time prediction models can be developed for green building construction projects of which the types can include residential, commercial, and 
industrial projects. In addition, assessment and comparison of schedule performance between green and traditional building construction projects can be done to set up a norm that can be used at the planning stage of green construction. Finally, it is also recommended to establish entire processes of project planning and feasibility studies for green projects as the processes directly affect schedule performance of green building construction projects.

\section{References}

Abdul-Rahman, H.; Wang, C.; Takin, R.; Wong, S. 2011. Project schedule influence by financial issues: evidence in the construction industry, Scientific Research and Essays 6(1): 205-212.

Ahmed, S. M.; Azhar, S.; Kappagntula, P.; Gollapudial, D. 2003. Delays in construction: a brief study of the Florida construction industry, in Proceeding of the 39th Annual ASC Conference, Clemson University, Clemson, SC, 257-266.

Al-Momani, A. H. 2000. Construction delay: a quantitative analysis, International Journal of Project Management 18(1): 51-59. http://dx.doi.org/10.1016/S0263-7863(98)00060-X

Alaghbari, W.; Kadir, M. R. A.; Salim, A.; Ernawati. 2007. The significant factors causing delay of building construction projects in Malaysia, Engineering, Construction and Architectural Management 14(2): 192-206. http://dx.doi.org/10.1108/09699980710731308

Arditi, R. D.; Akan, G. T.; Gurdamar, S. 1985. Reasons for delays in public projects in Turkey, Construction Management and Economics 3(2): 171-181. http://dx.doi.org/10.1080/01446198500000013

Assaf, S. A.; Al-Hejii, S. 2006. Causes of delay in large construction projects, International Journal of Project Management 24(4): 349-357. http://dx.doi.org/10.1016/j.ijproman.2005.11.010

Assaf, S. A.; AI-Khalil, M.; AI-Hazmi, M. 1995. Causes of delay in large building construction projects, Journal of Management in Engineering ASCE 11(2): 45-50.

http://dx.doi.org/10.1061/(ASCE)0742-597X(1995)11:2(45)

Beheiry, S. M. A.; Chong. W. K.; Haas, C. T. 2006. Examining the business impact of owner commitment to sustainability, Journal of Construction Engineering and Management ASCE 132(4): 384-92. http://dx.doi.org/10.1061/(ASCE)0733-9364(2006)132:4(384)

Bromilow, F. J. 1974. Measurement of scheduling of construction time and cost performance in the building industry, The Chartered Builder 10: 57-65

Building and Construction Authority (BCA) 2008. Code for environmental sustainability of buildings (version 1.0). Singapore: BCA. [Online], [cited 12 Feb 2011]. Available from Internet: http://www.bca.gov.sg/EnvSusLegislation/others/Env_Sus_Code.pdf

Building and Construction Authority (BCA) 2009. 2nd green building masterplan. Singapore: BCA. [Online], [cited $12 \mathrm{Feb} 2011$ ]. Available from Internet: http://www.bca.gov.sg/Newsroom/others/pr270409.pdf

Building and Construction Authority (BCA) 2011. Promising outlook for construction sector demand in 2011. Singapore: BCA. [Online], [cited 12 Feb 2011]. Available from Internet: http://www.bca.gov.sg/Newsroom/pr12012011_CPPS.html

Chalabi, F. A.; Camp, D. 1984. Causes of delays and overruns of construction projects in developing countries, in Proceedings of the International Council for Research and Innovation in Building and Construction (CIB), W65(3): 723-734.

Chan, D. W. M.; Kumaraswamy, M. M. 1995. Differing perception as to general causes of construction time overruns in Hong Kong, in Proceedings of the 11th Annual ARCOM Conference, Association of Researchers in Construction Management, York, United Kingdom, 318-329.

Chan, D. W. M.; Kumaraswamy, M. M. 1996. An evaluation of construction time performance in the building industry, Building and Environment 31(6): 569- 578.

http://dx.doi.org/10.1016/0360-1323(96)00031-5 
Chan, D. W. M.; Kumaraswamy, M. M. 1997. A comparative study of causes of time overruns in Hong Kong construction projects, International Journal of Project Management 15(1): 55-63. http://dx.doi.org/10.1016/S0263-7863(96)00039-7

Choi, C. 2009. Removing market barriers to green development: principles and action projects to promote widespread adoption of green development practices, Journal of Sustainable Real Estate 1(1): 107-138.

Council, U. G. B. 2003. Building Momentum: national trends and prospects for high-performance green buildings: based on the April 2002 green building roundtable and prepared for the US Senate Committee on Environment and Public Works. US Green Building Council. [Online], [cited 12 Feb 2011]. Available from Internet: http://www.usgbc.org/Docs/Resources/043003_hpgb_whitepaper.pdf

Eriksson, P. E.; Westerberg, M. 2011. Effects of cooperative procurement procedures on construction project performance. A conceptual framework, International Journal of Project Management 29(2): 197-208. http://dx.doi.org/10.1016/j.ijproman.2010.01.003

El-Razek, M. E.; Bassioni, H. A.; Mobarak, A. M. 2008. Causes of delay in building construction projects in Egypt, Journal of Construction Engineering and Management ASCE 134(11): 831-841. http://dx.doi.org/10.1061/(ASCE)0733-9364(2008)134:11(831)

Glavinich, T. E. 2008. Contractor's guide to green building construction. New Jersey: John Wiley \& Sons. http://dx.doi.org/10.1002/9780470259979

GreenBiz Group 2005. Green building technique: a two-minute briefing on key business environmental issues. Oakland: GreenBiz Group Inc. [Online], [cited 27 Feb 2011]. Available from Internet: http://www.greenbiz.com/sites/default/files/document/O16F4162.pdf

Hwang, B. G.; Lim, E. S. 2013. Critical success factors for key players and objectives: case study of Singapore, Journal of Construction Engineering and Management ASCE 139(2): 204-215. http://dx.doi.org/10.1061/(ASCE)CO.1943-7862.0000597

Hwang, B. G.; Ng, W. J. 2013. Project management knowledge and skills for green construction: overcoming challenges, International Journal of Project Management 31(2): 272-284. http://dx.doi.org/10.1016/j.ijproman.2012.05.004

Hwang, B. G.; Tan, J. S. 2012. Green building project management: obstacles and solutions for sustainable development, Sustainable Development 20(5): 335-349. http://dx.doi.org/10.1002/sd.492

Hwang, B. G.; Zhao, X.; Ng, S. Y. 2013. Identifying the critical factors affecting schedule performance of public housing projects, Habitat International 38: 214-221.

http://dx.doi.org/10.1016/j.habitatint.2012.06.008

Kats, G.; Alevantis, L.; Berman, A.; Mills, E.; Berkeley, L; Perlman, J. 2003. The costs and financial benefits of green buildings. Report to California’s Sustainable Building Task Force.

Kibert, C. J. 2008. Sustainable construction: green building design and delivery. New Jersey: John Wiley \& Sons.

Kua, H. W. 2006. The design of effective policies for the promotion of sustainable construction materials: PhD Thesis. Massachusetts Institute of Technology.

Kubba, S. 2010. Green construction project management and cost oversight. USA: Elsevier.

Lapinski, A. R.; Horman, M. J.; Riley, D. R. 2006. Lean processes for sustainable project delivery, Journal of Construction Engineering and Management ASCE 132(10): 1083-1091. http://dx.doi.org/10.1061/(ASCE)0733-9364(2006)132:10(1083)

Magent, C. S.; Korkmaz, S.; Klotz, L. E.; Riley, D. R. 2009. A design process evaluation method for sustainable buildings, Architectural Engineering and Design Management 5: 62-74. http://dx.doi.org/10.3763/aedm.2009.0907

Majld, M. Z.; McCaffer, R. 1998. Factors of non-excuseable delays that influence contractors' performance, Journal of Management in Engineering ASCE 14(3): 42-49. http://dx.doi.org/10.1061/(ASCE)0742-597X(1998)14:3(42)

Male, S. 1988. Faster building for commerce. UK: National Economic Development Office. 
Mansfield, N. R.; Ugwu, O. O.; Doran, T. 1994. Causes of delay and cost overruns in Nigerian construction projects, International Journal of Project Management 12(4): 254-260. http://dx.doi.org/10.1016/0263-7863(94)90050-7

Navon, R. 2005. Automated project performance control of construction projects, Automation in Construction 14(4): 467-476. http://dx.doi.org/10.1016/j.autcon.2004.09.006

Nofera, W.; Korkmaz, S. 2010. Design process integration for sustainable, high performance buildings. Engineering Project Organizations Conference, South Lake Tahoe, CA.

Nguyen, D. L.; Ogunlana, S.; Truong, Q.; Ka, C. L. 2004. Large construction projects in developing countries: a case study from Vietnam, International Journal of Project Management 22(7): 553-561. http://dx.doi.org/10.1016/j.ijproman.2004.03.004

Odeh, A. M.; Battaineh, H. T. 2002. Causes of construction delays: traditional contracts, International Journal of Project Management 20(1): 67-73. http://dx.doi.org/10.1016/S0263-7863(00)00037-5

Ogunlana, S. O.; Promkuntong, K.; Jearkjirm, V. 1996. Construction delays in a fast growing economy: comparing Thailand with other economies, International Journal of Project Management 14(1):37-45. http://dx.doi.org/10.1016/0263-7863(95)00052-6

Pitt, M.; Tucker, M.; Riley, M.; Longden, J. 2008. Towards sustainable construction: promotion and best practices, Construction Innovation 9(2): 201-224. http://dx.doi.org/10.1108/14714170910950830

Project Management Institute 2004. A guide to the project management body of knowledge (PMBOK Guide). $3^{\text {rd }}$ ed. USA: Project Management Institute.

Sambasivan, M.; Yau, W. S. 2007. Causes and effects of delays in Malaysian construction industry, International Journal of Project Management 25(5): 517-526. http://dx.doi.org/10.1016/j.ijproman.2006.11.007

Snell, C.; Callahan, T. 2005. Building green: a complete how-to guide to alternative building methods: earth, plaster, straw bale, cordwood, cob, living roofs. 1st ed. New York: Lark Books.

The Business Times 2010. Making their mark on the environment. Singapore: environmental directory [online], [cited 10 December 2011]. Available from Internet:

http://www.greensingapore.com/Singlenews.aspx?DirID=55\&rec_code $=591674$

Thompson, P. 1991. The client role in project management, International Journal of Project Management 9(2): 90-92. http://dx.doi.org/10.1016/0263-7863(91)90066-5

Tobias, C. 2010. Outlook for carbon markets uncertain, Eco-Business [online], [cited 10 December 2011]. Available from Internet: http://www.eco-business.com/blog/outlook-carbon-markets-uncertain/

Walker, D. H. T. 1995. An investigation into construction time performance, Construction Management and Economics 13(3): 263-274. http://dx.doi.org/10.1080/01446199500000030

Zhang, X.; Platten, A.; Shen, L. 2011. Green property development practice in China: costs and barriers. Building and Environment 46(1): 2153-2160. http://dx.doi.org/10.1016/j.buildenv.2011.04.031

Bon Gang HWANG (Dr) has been working as an Assistant Professor in the Department of Building at National University of Singapore Since 2008. He has several years of experience in the construction industry, working with Samsung Engineering \& Construction Company, Korea, and Construction Industry Institute, USA. In his doctoral research, he specialized in developing industry-specific performance indicators and measurement /analysis/reporting systems. He has over 50 publications including journal papers, conference papers, and in the areas listed. His current research interests are in the areas of sustainable construction project management, performance assessment and improvement, rework identification and analysis, and risk management.

Lay Peng LEONG (Ms) graduated from the National University of Singapore in 2011 in Project and Facilities Management. She has been with EC Harris Singapore Pte Ltd, Singapore as an Cost Control Executive since 2011. 